\title{
KAJIAN ALIH FUNGSI LAHAN PERTANIAN PANGAN \\ DI KOTA TASIKMALAYA
}

\author{
Oleh: \\ DJONI \\ FAKULTAS PERTANIAN UNIVERSITAS SILIWANGI TASIKMALAYA \\ email: djoniyudhaatmaja21@gmail.com \\ SUPRIANTO \\ FAKULTAS PERTANIAN UNIVERSITAS SILIWANGI TASIKMALAYA \\ email: supriantoprie56@gmail.com \\ ERI CAHRIAL \\ FAKULTAS PERTANIAN UNIVERSITAS SILIWANGI TASIKMALAYA
}

email: eri.cahrial@yahoo.co.id

\begin{abstract}
Abstrak
Penelitian ini bertujuan untuk mengidentifikasi luas dan klasifikasi lahan pertanian pangan eksisting; identifikasi rata-rata luas lahan pertanian pangan yang beralih fungsi; identifikasi faktor-faktor yang menyebabkan terjadinya alih fungsi lahan pertanian pangan; dan menyusun strategi pengendalian alih fungsi lahan pertanian pangan di Kota Tasikmalaya.Berdasarkan hasil analisis, hasil penelitian ini, dapat disimpulkan bahwa luas lahan pertanian Kota Tasikmalaya 12.519 Ha, terdiri dari lahan sawah 5.993 Ha dan lahan pertanian bukan sawah 6.526 hektar. Berdasarkan sistem pengairannnya lahan sawah terdiri dari lahan sawah irigasi 5.055 hektar dan tadah hujan 938 hektar; Dalam periode waktu delapan tahun terakhir terjadi alih fungsi lahan sawah seluas 191 Ha. Faktanya dilapangan luas lahan pertanian yang beralih fungsi lebih luas lagi, karena cukup banyak satuan hamparan lahan sawah yang tidak tercatat beralih fungsi; Faktor-faktor yang mempengaruhi terjadinya alih fungsi lahan pertanian dapat dibagi kedalam dua kategori, yaitu: yaitu faktor internal dan faktor ekternal. Faktor internal meliputi Faktor Teknis; Faktor Ekonomis dan Faktor sosial. Sementara faktor ekternal yang mempenagruhi alih fungsi lahan pertanian diantaranya adalah laju pertumbuhan penduduk, kebijakan pembangunan pemerintah (daerah) dan Rencana Tata Ruang Wilayah (RTRW). Rekomendasi pengendalian alih fungsi lahan pertanian ini berbasiskan pada faktor-faktor yang menyababkan alih fungsi lahan pertanian tersebut.
\end{abstract}

Kata kunci : Alih Fungsi Lahan Pertnian

\section{PENDAHULUAN}

Luas lahan pertanian per kapita penduduk cenderung semakin sempit, sehingga melahirkan petani-petani gurem dengan luas lahan garapan kurang dari 0,5 hektar. Kepemilikan atau penguasaan lahan pertanian rata-rata di Pulau Jawa dan Bali lebih sempit lagi, rata-rata 0,34 hektar per rumah tangga petani. Kondisi ini akan berimplikasi pada tingkat kesejahteraan petani.

Permasalahan lain yang tak kalah pentingnya dan menjadi topik kajian ini adalah tingginya alih fungsi lahan pertanian menjadi lahan non-pertanian. Laju alih fungsi lahan pertanian sudah sangat mengkhawatirkan dengan angka mencapai 100 ribu hektare per tahun,sementara kemampuan pemerintah dan msyarakat dalam pencetakan lahan sawah kurang dari 30.000 hektar per tahun.

Berkaitan dengan uraian tersebut di atas, salah satu upaya untuk mewujudkan ketahanan dan kedaulatan pangan perlu dilakukan upaya pengendalian alih fungsi lahan pertanian pangan. Upaya tersebut ditempuh melalui perlindungan, dengan mempertahankan dan menambah luas lahan serta menetapkan kawasan pertanian pangan berkelanjutan pada kawasan peruntukan pertanian. Penetapan lahan pertanian pangan berlanjutan ini dimaksudkan agar lahan pertanian yang sudah ada dapat dipertahankan keberadaannya bahkan dapat 


\section{AIMBAR AGRIBISNIS}

ditingkatkan baik luasan secara makro maupun luas pengelolaan lahan per kapita petani.

Berkaitan dengan kondisi tersebut di atas, setiap daerah otonomi diharapkan agar tidak terlalu mudah memberikan peluang untuk terjadinya alih fungsi lahan pertanian pangan. Pemerintah (daerah) berkewajiban mempertahankan lahan pertanian pangan agar tetap fungsinya berkelanjutan. Namun demikian upaya Perlindungan Lahan Pertanian melalui Undang-Undang No. 41 tahun 2009. sampai saat ini belum sepenuhnya efektif dan sinergi dengan tata ruang. Tata ruang selayaknya menetapkan lahan-lahan mana yang harus dipertahankan, dan menetapkan lahan yang dapat beralih fungsi.

Berdasarkan uraian latar belakang masalah tersebut di atas, dapat dirumuskan bahwa inti permasalahan kajian ini adalah adanya kesenjangan antara kebutuhan lahan yang semakin luas untuk memenuhi kebutuhan produksi bahan pangan yang semakin besar jumlahnya, seiring dengan samakin besarnya jumlah penduduk. Namun disisi lain kebutuhan lahan untuk aktivitas diluar pertanian pun tak kalah besarnya. Dalam kaitannya dengan kesenjangan tersebut kajian ini mencoba mengidentifikasi, menghitung dan menyusun analisis :

- luas dan klasifikasi lahan pertanian pangan di wilayah Kota Tasikmalaya pada kondisi eksisting;

- rata-rata luas lahan pertanian pangan yang beralih fungsi ke penggunaan lain setiap tahun;

- identifikasi faktor-faktor yang menyebabkan terjadinya alih fungsi lahan pertanian;

- strategi pengendalian alih fungsi lahan pertanian.

Hasil kajian ini diharapkan bermanfaat sebagai acuan penyusunan perencanaan, penetapan, pemanfaatan, dan pengendalian lahan pertanian pangan.

Secara rinci tujuan dilakukannya kajian ini adalah untuk:

- mengidentifikasi luas dan klasifikasi lahan pertanian pangan eksisting ;
- mengidentifikasi rata-rata luas lahan pertanian pangan yang beralih fungsi ke penggunaan lain setiap tahun;

- mengidentifikasi faktor-faktor yang menyebabkan terjadinya alih fungsi lahan pertanian pangan;

- menyusun strategi pengendalian alih fungsi lahan pertanian pangan

\section{BAHAN DAN METODE}

\section{Metode}

Metode yang digunakan adalah descritive survey, yaitu penelitian yang memberi gambaran dari suatu gejala dan pokok perhatiannya tertuju pada pengukuran yang tepat dari satu atau lebih variabel dalam satu kelompok atau dalam sampel dari kelompok tertentu itu.

\section{Kerangka Alur Pikir}

Kerangka alur pikir kajian dapat digambarkan sebagai berikut.

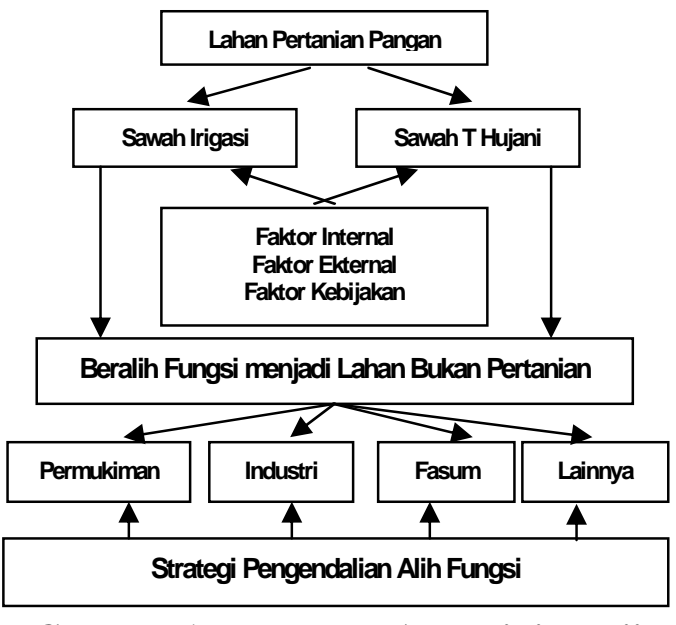

Gambar 1. Kerangka Alur Pikir Kajian

\section{HASIL DAN PEMBAHASAN \\ Faktor Yang Mempengaruhi Alih \\ Fungsi Lahan}

Alih fungsi lahan pertanian pangan dapat dipengaruhi oleh faktor internal dan faktor ekternal.

\section{Faktor Internal}

a. Faktor Teknis

Faktor teknis yang mempengaruhi karakteristik fisik lahan usahatani diantaranya 


\section{Kajian Alih Fungsi Lahan Pertanian Pangan \\ Di Kota Tasikmalaya \\ DJONI, SUPRIANTO DAN ERI CAHRIAL}

adalah : (a) Sistem pengairan (b) Kondisi kesuburan, (c) jenis tanah (d) Indeks pertanaman (IP), (e) Kondisi agroklimat, (f) Kondisi infrastuktur dasar dan (g) Produktivitas dan lain-lain.

\section{Tabel 1. Karakteristik Lahan Sawah di Kota Tasikmalaya}

\begin{tabular}{|c|l|l|l|}
\hline $\begin{array}{c}\text { N } \\
\text { o }\end{array}$ & \multicolumn{1}{|c|}{ Uraian } & \multicolumn{1}{|c|}{$\begin{array}{c}\text { Kondisi } \\
\text { Ekisting }\end{array}$} & Ket*) \\
\hline 1 & $\begin{array}{l}\text { Sistem } \\
\text { Pengairan }\end{array}$ & Irigasi t hujan & Terpenuhi \\
\cline { 2 - 4 } 2 & Jenis Tanah & $\begin{array}{l}\text { Aluvial, latosol, } \\
\text { podhsolik kuning }\end{array}$ & Sesuai \\
\multirow{2}{*}{3} & $\begin{array}{l}\text { Kesuburan } \\
\text { lahan }\end{array}$ & unsur hara makro & Terpenuhi \\
\cline { 2 - 4 } 4 & $\begin{array}{l}\text { Indeks } \\
\text { Pertanaman }\end{array}$ & IP 2-3 & $\begin{array}{l}\text { PI minimal= } \\
1\end{array}$ \\
\cline { 2 - 4 } 5 & $\begin{array}{l}\text { Kondisi } \\
\text { Agroklimat }\end{array}$ & Tipe D3 & Sesuai \\
\cline { 2 - 4 } 7 & Produktivitas & 62 kwt & $\begin{array}{l}\text { Syarat min } \\
30 \mathrm{kw}\end{array}$ \\
\hline
\end{tabular}

Sumber: Dinas Pertanian Perikanan dan Kehutanan Kota Tasikmalaya 2015

\section{*) Kesesuaian dengan Syarat dan Kriteria LP2B}

Diantara berbagai faktor tersebut di atas yang sering kali menjadi kendala dalam penyelenggaraan usahatani di Kota Tasikmalaya adalah kecukupan air untuk tanaman pada lahan usahatani. Hal ini terjadi pada musim tanam gadu di lahan-lahan sawah yang berada di bagian hilir dari saluran irigasi. Dengan demikian walaupun dalam klasifikasi pengairan lahan sawah tersebut termasuk kategori lahan irigasi, namun sering mengalami kekurangan air. Faktor penyebab utamanya karena debit air pada saluran irigasi yang bersangkutan tidak mencukupi untuk mengairi seluruh lahan sawah di bagian hilir. Sedangkan faktor teknis lain seperti yang telah disebutkan di atas, yang berkaitan dengan karakteristik lahan sawah di Kota Tasikmalaya dapat memenuhi kriteria dan syarat Peraturan Pemerintah Nomor 1 Tahun 2011, untuk dijadikan lahan pertanian pangan berkelanjutan.

\section{b. Faktor Ekonomis \\ Skala Usahatani}

Penguasaanlahan usahatani di Kota Tasikmalaya yang luasnya dibawah 1 hektar jumlahnya cukup besar mencapai proporsi \pm 93 persen. Kurang lebih 64 persen adalah satuan lahan usahatani dibawah 0.50 ha; Kurang lebih 29 persen satuan usahatani yang luasnya antara (0.51-1,00) hektar; Sementara satuan lahan usahatani >1 hektar proporsinya hanya 7 persen. Usahatani yang tidak mencapai saka ekonomis, saat akan menjual hasil produksi juga bermasalah, yaitu akan menanggung beban biaya penjualan (marketing cost) yang tinggi per satuan produknya. Pada gilirannya harga produk hasil pertanian yang dihasilkan manjadi kurang bersaing.

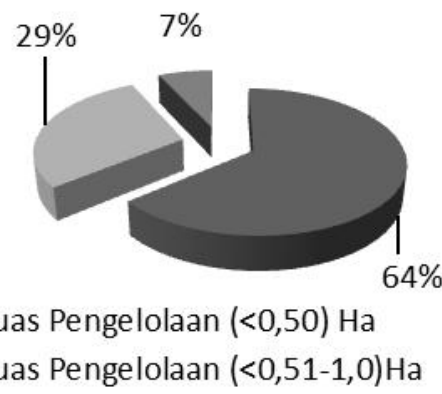

\section{Gambar 2 Proporsi Satuan Usahatani Berdasarkan Luas Garapan di Kota Tasikmalaya Tahun 2013}

Petani kecil yang penguasaan lahan usahataninya sempit atau biasa disebut petani gurem, akan mengalami hambatan dalam upaya mengalihkan sistem pengelolaan yang bersifat subsisten ke pengelolaan usahatani yang berorientasi komersial. Kecilnya volume produksi dari setiap satuan usahatani mendorong terbentuknya struktur pasar hasil pertanian yang oligopsoni. Padahal struktur pasar yang oligopsoni melemahkan posisi tawar menawar (bargaining position) petani di pasar hasil usahatani. Dalam posisi tawar petani yang lemah petani hanya sebagai price taker bukan price maker sebagaimana yang diharapkan.

Selanjutnya, satuan lahan garapan usahatani yang terlalu kecil tidak akan mampu menjamin kehidupan dan kesejahteraan petani dan keluarganya. Lahan usahatani yang tidak layak secara ekonomis tidak memiliki insentif untuk dikelola dengan sungguh-sungguh oleh petani. Pada gilirannya satuan lahan usahatani yang terlalu sempit akan lebih mudah beralih fungsi, sementara pengelolanya beralih profesi 


\section{AIMBAR AgRIBISNIS}

ke usaha pertanian lain atau alih profesi keluar sektor pertanian. Hal ini selaras seperti yang dikatakan Fadholi Hernanto (1984) yang menyoroti pengelola lahan yang satuan luasnya dibawah sekala ekonomis banyak beralih profesi sementara lahan usahataninya beralih fungsi.

\section{Rentabilitas Usahatani}

Petani akan berusaha mencari perpaduan dalam pemanfaatan sumberdaya yang mereka miliki agar mendatangkan keuntungan finansial dari usahatani yang dijalankannya (Soekartawi, 1995). Petani dalam menjalankan usahataninya tentu berharap akan mendapatkan penerimaan yang lebih besar dari biaya produksi yang telah dikeluarkan. Tetapi kenyataannya tidak selamanya sesuai dengan harapan, bahkan tidak sedikit petani yang mengalami kerugian.

Kerugian yang dialami petani pada umumnya "kerugian yang tidak kentara". Biasanya petani kurang jeli memperhitungkan biaya-biaya yang mereka keluarkan. Petani hampir tidak pernah menghitung curahan tenaga kerja diri dan keluarganya sebagai komponen biaya uasahatani. Petani juga kadang-kadang tidak memperhitungkan harga jual hasil produksinya yang berlaku di pasaran, karena hasil produksinya dikonsumsi untuk keluarga.

Hasil analisis kelayakan finansial usahatani menunjukkan Revenue Cost Rotio (R/C) usahatani padi di Kota Tasikmalaya lebih besar dari satu $(\mathrm{R} / \mathrm{C}>1)$; yaitu sebesar 1,23 untuk petani penyakap dan 1,51 untuk petani pemilik penggarap. Artinya pengelolaan usahatani yang dilakukan dilihat dari rasio penerimaan dengan biaya usahatani adalah layak. Namun demikian apabila dilihat secara nominal rata-rata pendapatan (laba) dari hasil pengelolaan usahatani padi tersebut kurang layak.

Laba usahatani tanaman pangan yang dibawa kerumah (take home payment) pada luas lahan setengah $(0,5)$ hektar adalah Rp 2.221.250 untuk petani penggarap, dan Rp 3.976.250, untuk petani pemilik per musim, atau setara dengan Rp 740.417 per bulan untuk petani penggarap; dan Rp 1.325.470 per bulan untuk petani pemilik.

Dalam kondisi seperti tersebut di atas, walaupun usahatani yang dijalankan adalah layak dilihat dari rasio peneriman dengan biaya $(\mathrm{R} / \mathrm{C})$, namun dilihat dari nominal laba yang diperoleh usahatani yang dijalankan tidak dapat memenuhi seluruh kebutuhan keluarga petani. Dengan hanya mengelola usahatani padi sawah yang luasnya kurang dari setengah hektar, penghasilan yang diperoleh petani masih dibawah upah minimum regional (UMR) Kota Tasikmalaya. Sebagai catatan UMR Kota Tasikmalaya adalah Rp 1.800.000.

Dalam kondisi penerimaan usahatani tidak dapat memenuhi kebutuhan dasar keluarga, petani masih memerlukan sumber pendapatan lain selain dari usahatani. Petani terdorong untuk mencari pekerjaan lain sebagai sumber pendapatan tambahannya, dan tidak tertutup kemungkinannya petani beralih profesi. Sementara lahan usahatani yang dikelolanya kurang mendapatkan perhatian yang sungguhsungguh, bahkan tidak sedikit akhirnya yang di jual beralih status kepemilikan, yang pada gilirannnya berujung pada terjadinya alih fungsi lahan usahatani ke penggunaan lain.

Rendahnya penerimaan (revenue) hasil pertanian dibandingkan dengan biaya produksi (cost of production) sementara hasil di sektor non pertanian (industri), sewa tanah, dan tingginya harga tanah jika di jual tanah membuat banyak petani-petani yang mengalih fungsikan lahannya ke bidang non pertanian. Tidak sedikit petani yang menjual lahan pertaniannya kepada pemilik modal untuk kegiatan non pertanian. Selain itu karena terdesak kebutuhan keluarga seperti untuk biaya pendidikan, kesehatan sering kali membuat petani tidak mempunysi pilihan lain untuk menjual sebagian atau seluruh lahan usahataninya.

Penduduk yang bermata-pencaharian pada bidang usaha yang terkait dengan sektor pertanian di Kota Tasikmalaya mencapai proporsi lebih dari 40 persen. Sementara kontribusi sektor pertanian terhadap PDRB hanya mencapai \pm 15 persen. Hal ini menunjukan bahwa secara agregat curahan sumberdaya dan tenaga kerja di sektor pertanian 


\section{Kajian Alih Fungsi Lahan Pertanian Pangan \\ Di Kota Tasikmalaya \\ DJONI, SUPRIANTO DAN ERI CAHRIAL}

mendapatkan kompensasi yang relative lebih rendah dibandingkan dengan kompensasi yang diterima untuk curahan sumberdaya dan tenaga kerja pada sektor lain.

\section{c. Faktor Sosial}

Persepsi masyarakat terhadap lahan pertanian, proses fragmentasi lahan pertanian dan persepsi generasi muda terhadap profesi petani, memiliki kontribusi terhadap terjadinya alih fungsi lahan pertanian ke penggunaan lain.

\section{Persepsi Terhadap Kepemilikan Lahan.}

Undang-undang nomor 5 tahun 1960 tentang Peraturan Dasar Pokok-pokok Agraria, pasal 4 ayat (1) dan (2) menentukan adanya macam-macam hak atas tanah yang dipunyai oleh individu maupun badan hukum. Dinyatakan lebih lanjut dalam pasal 6 bahwa semua hak atas tanah mempunyai fungsi sosial. Hak atas tanah apapun pada seseorang tidak dapat dibenarkan apabila tanah itu dipergunakan atau tidak dipergunakan sematamata untuk kepentingan pribadinya, apalagi kalau hal itu menimbulkan kerugian bagi masyarakat.

$\begin{array}{rrr}\text { Penggunaan } & \text { tanah selayaknya } \\ \text { bermanfaat bagi kesejahteraan yang }\end{array}$ memilikinya, juga dapat bermanfaat bagi masyarakat dan negara. Sekalipun penguasaan tanah bestatus hak milik, namun pada saatnya pemerintah berkepentingan untuk keperluan umum yang lebih tinggi urgensinya, maka pemilik tanah harus menyerahkannya kepada pemerintah untuk keperluan yang lebih besar dari kepentingan individu. Tentu saja penyerahan tersebut melalui prosedur dan administrasi serta kompensasi yang sepadan.

Dalam kenyataannya di lapangan masih banyak pihak termasuk para petani yang menganggap hak milik atas tanah adalah "mutlak", sehingga dapat diartikan penggunaannya tergantung pada kehendak pemiliknya sendiri. Dalam kondisi seperti ini untuk mempertahankan suatu hamparan lahan agar tetap fungsinya sebagai lahan pertanian akan mengalami kesulitan. Tanah pada umumnya dipandang sebagai "asset" bagi pemiliknya. "nilai ekonomi" atas tanah lebih dipahami masyarakat dibandingkan dengan "fungsi sosialnya". Maka oleh sebab itu dalam kondisi seperti ini lahan pertanian lebih mudah beralih fungsi, sesuai dengan keinginan pemiliknya menjadi peruntukan lain ketika dihadapkan dengan nilai ekonomi.

Berdasarkan fenomena tersebut di atas, dalam upaya mewujudkan ketersediaan lahan pertanian, disamping dilakukan melalui pendekatan sosial, juga harus dilakukan dengan pendekatan (nilai) ekonomis. Pemberian insentif atas kepemilikan lahan-lahan yang difungsikan sebagai lahan pertanian pangan berkelanjutan merupakan salah satu pendekatan yang bijak dan harus dipikirkan lebih lanjut implementasinya.

\section{Status Pelaku Usahatani}

Berdasarkan status penguasaan lahan yang digarapnya, pelaku usahatani dapat digolongkan kedalam empat kategori, yaitu: Petani pemilik, petani pemilik penggarap, petani penggarap dan buruh tani. Petani pemilik dengan proporsi $\pm 6 \%$. adalah pemilik lahan usahatani namun tidak menggarap lahan usahataninya. Lahan usahatani yang dimiliki digarap oleh penyakap, dengan mendapatkan kompensasi dari orang yang menggarap atau penyakap tersebut. Petani pemilik penggarap $\pm 70 \%$ adalah petani yang menggarap lahan usahatani miliknya sendiri; Penggarap/penyakap (16\%) adalah orang yang mengerjakan lahan usahatani milik orang lain, termasuk penyewa atau penggadai; Buruh tani \pm $8 \%$ adalah orang yang mendapat upah atas curahan tenaga kerja pada lahan usahatani.

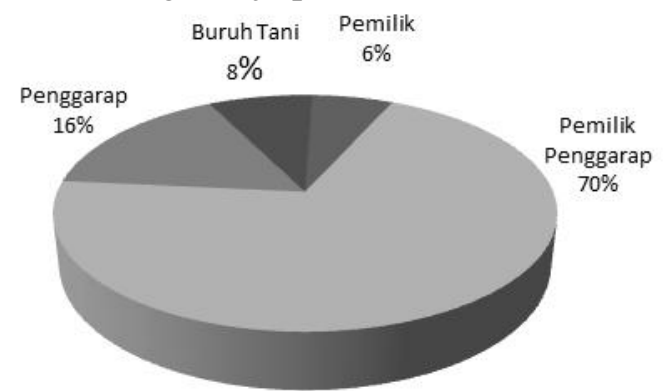

Gambar 3. Proporsi Status Pelaku Usahatani di Kota Tasikmalaya Tahun 2013

Diantara pelaku usahatani tersebut di atas, yang paling rentan lahan usahataninya beralih fungsi adalah lahan usahatani dari 


\section{AIMBAR AgRIBISNIS}

pelaku usahatani yang berstatus "pemilik" dan penggarap atau "penyakap". Pemilik biasanya lebih memandang sebagai aset terhadap lahan usahatani. Nilai ekonomis lebih mendominasi pertimbangan keputusan atas lahan usahataninya. Sementara penyakap mungkin hanya memiliki ikatan emosional dengan lahan garapan usahatani namun keputusan atas lahan usahatani yang digarapnya sangat tergantung pada pemilik. Pemilik penggarap selain memiliki ikatan emosional juga memiliki "power" untuk memutuskan perlakuan terhadap lahan usahataninya. Maka diantara pelaku usahatani tersebut di atas, yang relatif mudah dalam pengendalian lahan usahatani adalah lahan usahatani pemilik penggarap.

\section{Fragmenasi Lahan Pertanian.}

Fragmentasi lahan pertanian merupakan suatu tahapan proses dalam evolusi pengelolaan pertanian di mana suatu suatu unit usahatani terdiri dari sejumlah persil lahan yang terpisah, terpencar-pencar dalam suatu area yang luas. Dalam sudut pandang yang lebih umum, pengertian mengenai fragmentasi lahan lebih mudah dipahami jika dikaitkan dengan prosesnya. Dalam hal ini, fragmentasi lahan pertanian sebagai proses segregasi spasial menjadi lebih banyak entitas sehingga memengaruhi fungsi optimalnya. Fragmentasi lahan berawal dari pilihan positif pemiliknya, yakni terkait dengan pertimbangan yang didasarkan atas ekspektasi manfaat ekonomis yang dapat dipetiknya ataupun terkait dengan upaya memperkecil risiko yang mungkin akan dihadapinya.

Bercermin dari sejumlah kasus menunjukkan bahwa fragmentasi lahan pertanian berkontribusi pada:

- terhambatnya peningkatan produktivitas usahatani;

- rendahnya efisiensi pengadaan sarana produksi maupun pemasaran produksi hasil pertanian;

- inefisiensi yang terjadi pada ongkos pengelolaan program-program berbantuan, subsidi, dan lain-lain di bidang pertanian;

Pada gilirannya, fragmentasi lahan pertanian menjadi salah satu faktor pendorong laju meningkatnya konversi lahan pertanian.
Proses alih penguasaan atau kepemilikan lahan usahatani dari satu generasi ke generasi berikutnya merupakan suatu proses alamiah dan menjadi suatu keniscayaan. Secara akumulatif dalam jangka panjang proses tersebut menyebabkan rata-rata satuan luas usahatani yang sudah sempit menjadi semakin sempit. Sementara usahatani yang sempit, berada dibawah skala ekonomis, tidak dapat menjadi tumpuan kehidupan keluarga petani. Rendahnya intensitas pengelolaan usahatani akan menyebabkan produktivitasnya juga rendah. Pada gilirannya usahatani yang tidak dapat menjamin kebutuhan keluarga akan mudah ditinggalkan petani dan lahan usahatani cenderung beralih fungsi.

\section{Minat Generasi Muda}

Profesi petani adalah sebagailah profesi yang sangat mulia, dapat menyediakan bahan pangan dan bahan sandang serta bahan perumahan (papan) untuk banyak orang. Namun seiring dengan berjalannya waktu, ditunjang dengan terjadinya transformasi struktur perekonomian lahan pertanian tidak lagi menjadi simbul status sosial dalam masyarakat. Dalam sudut pandang banyak orang, terutama sudut pandang generasi muda, profesi sebagai petani dianggap kurang bergengsi. Kalau menggunakan bahasa anak muda sekarang profesi petani dianggap "tidak keren". Kenyataan ini berakibat pada profesi sebagai petani tidak populer dan kurang diminati generasi muda. Tidak sedikit penduduk yang berprofesi sebagai petani, namun tidak mencantumkan "petani" dalam kartu penduduknya (KTP) dalam identitas pekerjaannya.

Persepsi masyarakat terhadap profesi petani seperti ini usahatani menjadi pilihan terahir sebagai sandaran penghidupan. Selain itu semakin banyaknya patani yang berkeinginan beralih profesi dari petani untuk menekuni usaha dibidang lain, dan berdampak semakin banyaknya lahan pertanian pangan yang tidak digarap dengan sungguh-sungguh. Lahan yang tidak digarap dengan sungguhsungguh sangat mudah untuk beralaih kepemilikan dan alih fungsi. 


\section{Kajian Alih Fungsi Lahan Pertanian Pangan \\ Di Kota Tasikmalaya \\ DJONI, SUPRIANTO DAN ERI CAHRIAL}

Semenjak wilayah kajian menjadi daerah otonomi Kota Tasikmalaya, orientasi pembangunan ekonomi daerah tidak lagi berbasiskan pada sektor pertanian. Generasi muda juga lebih memilih profesi di sektor industri dan jasa yang dianggapnya lebih menjamin kehidupan mereka dan memiliki nilai tukar ekonomis yang lebih tinggi. Dalam kondisi seperti ini usahatani termarginalkan. Lahan usahatani cenderung dijual, kepada pemilik modal untuk membangun kegiatan usaha non pertanian sementara hasil penjualan usahatani tersebut oleh penjual lahan digunakan untuk modal usaha di sektor lain.

Usaha dibidang pertanian (on farm) khususnya usahatani padi, kurang diminati oleh penduduk yang berusia muda. Kalupun pada umumnya petani masih dalam usia produktif, namun rata-rata > 40 sampai 60 tahun. Generasi muda lebih tertarik pada usaha dibidang industri dan jasa, sekalipun hanya sebagai buruh. Kondisi ini merupakan suatu gambaran bahwa sektor pertanian, belum mampu memberikan imbalan kompensasi yang setara dengan sektor usaha lain atas sumberdaya dan tenaga kerja yang dicurahkan.

\section{Faktor Ekternal}

Tiga faktor ekternal elementer yang mendorong terjadinya alih fungsi lahan pertanian pangan ke penggunaan lain, yaitu: laju pertumbuhan penduduk; transpormasi perekonomian daerah; dan kebijakan pemerintah (daerah).

\section{a. Laju Pertumbuhan Penduduk}

Laju pertumbuhan penduduk (LPP) Kota Tasikmalaya dalam sepuluh tahun terakhir mengalami kecenderungan yang menurun. Dari laju pertumbuhan penduduk sebesar 1,98 persen pada awal tahun 2003, dalam lima tahun terakhir berturut-turut menjadi 1,66 persen tahun 2009, menjadi 0,84 persen tahun 2010, menjadi 0,67 persen tahun 2011 dan pada tahun 2014 menjadi 0,48 persen. Walapun laju pertumbuhan penduduk mengalami penurunan, namun jumlah penduduk secara akumulatif, seiring dengan berjalannya waktu akan terus bertambah.
Jumlah penduduk Kota Tasikmalaya pada tahun 2014 adalah 654.794 jiwa, dengan asumsi laju pertumbuhan penduduk sebelas tahun kedepan adalah sama dengan laju pertumbuhan penduduk tahun 2014. Maka dapat diprediksi jumlah penduduk Kota Tasikmalaya 654.794 jiwa pada tahun 2013, akan menjadi 690.209 jiwa pada tahun 2025.Akumulasi pertambahan jumlah penduduk tersebut mengakibatkan semakin banyak pula sumberdaya yang dibutuhkan untuk memenuhi kebutuhan hidupnya, termasuk didalamnya kebutuhan lahan untuk perumahan dan fasilitas umum.

Berdasarkan hasil identifikasi lahan yang beralih fungsi menjadi lahan perumahan di Kota Tasikmalaya selama 8 tahun terakhir mencapai 20 hektar; Sedangkan luas lahan yang beralih fungsi menjadi jalan dan jembatan 50 hektar; Fasilitas umum lainnya mencapai 26 hektar dan lain-lain, sehingga jumlah lahan yang beralih fungsi sampai tahun 2014 mencapai seluas 191 hektar.

Alih fungsi lahan tersebut akan terus berlangsung seiring dengan berjalannya waktu ditunjang dengan transpormasi dan laju pertumbuhan ekonomi (LPE) daerah yang semakin baik. Sebagai ilustrasi, dengan asumsi:

- Setiap suatu keluarga rata-rata membutuhkan lahan untuk membangun rumah pada lahan seluas 8 tumbak;

- Berdasarkan Norma Keluarga Kecil Bahagia dan Sejahtera (NKKBS) setiap keluarga terdiri dari 4 orang;

Berdasarkan konsiderasi tersebut di atas dapat diproyeksikan kebutuhan lahan untuk perumahan setiap tahun, yang berpotensi menggeser lahan pertanian beralih fungsi.

\section{b. Kebijakan Pemerintah (Daerah)}

Melihat visi dan misi pembangunan Kota Tasikmalaya, tidak mengisyaratkan bahwa sektor pertanian menjadi basis atau setidaknya memiliki peran yang cukup penting dalam pembangunan Kota Tasikmalaya. Sektor pertanian khususnya tanaman pangan tidak menjadi prioritas dalam pembangunan Kota Tasikmalaya. Kebijakan ini menjadi sangat berpengaruh terhadap keberadaan sumberdaya lahan pertanian. Pengaruh kebijakan umum 


\section{A MIMBAR AGRIBISNIS

pembangunan Kota Tasikmalaya terhadap lahan pertanian pangan dapat dilihat lebih kongkrit dalam arahan rencana tata ruang.

\section{Rekomendasi Pengendalian}

Rekomendasi pengendalian alih fungsi lahan pertanian pangan di Kota Tasikmalaya ini dapat dirinci meliputi: Pengendalian alih fungsi lahan pertanian yang disebabkan oleh faktor eksternal yang terdiri dari :

- Pengendalian penggunaan lahan agar sesuai dengan Rencana Tata Ruang Wilayah (RTRW).

- Pengendalian tahapan penggunaan lahan Sedangkan pengendalian lahan pertanian yang disebabkan oleh faktor internal dilakukan dapat dilakukan melalui berbagai pendekatan aspek sosial-ekonomi usahatani.

\section{Pengendalian Alih Fungsi Lahan Pertanian Berbasis RTRW}

Pengendalian Alih Fungsi Lahan Pertanian Berbasis Rencana Tata Ruang adalah pengendalian alih fungsi lahan pertanian di Kota Tasikmalaya agar alih fungsi yang terjadi tidak menyimpang dari arahan rencana pola ruang yang telah ditetapkan berdasarkan RTRW Kota Tasikmalaya Tahun 2011-2031.

Peruntukkan lahan untuk zona lindung 20\%; perairan $1 \%$; jalan $2 \%$ dan zone budidaya $77 \%$

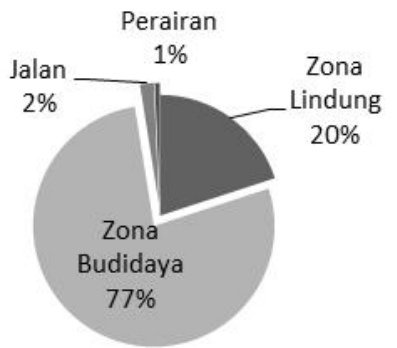

\section{Gambar 4. Arahan/Rencana Pola Ruang Kota Tasikmalaya}

Lahan pertanian pangan berdasarkan Pola Ruang berada pada zona budidaya yang meliputi proporsi area sebesar $77 \%$. Sedangkan zone lindung meliputi areal sampadan sungai, sempadan danau, aliran lahar, hutan/taman kota. Jalur hijau jalan, pemakaman, sempadan sutet, sempadan rel kereta api dan kawasan resapan.
Berdasarkan Peraturan Daerah Kota Tasikmalaya Nomor 4 Tahun 2012 paragraf 7 Pasal 49 ayat 2, Rencana Tata Ruang Wilayah (RTRW) Kota Tasikmalaya Tahun 2011-2031, peruntukan lahan pertanian pangan ini hanya meliputi area seluas 492 hektar, tersebar di 4 (empat) wilayah kecamatan, yaitu Kecamatan Purbaratu, Cibeureum, Mangkubumi dan Kawalu. (Rincian Blok dan luas hamparan lahan pertanian dimaksud dapat dilihat dalam Peta di Naskah Lengkap).

\section{Pengendalian Tahapan Alih Fungsi}

Seperti telah dibahas dalam uraian sebelumnya, bahwa luas lahan sawah eksisting di Kota Tasikmalaya 5.993 hektar, sedangkan yang luas lahan pertanian pangan yang dicanangkan menurut Rencana Tata Ruang Wilayah hanya 492 hektar. Artinya sebagian besar hamparan lahan pertanian pangan yang sekarang ini berupa lahan sawah status hukum peruntukkannya tidak lagi untuk lahan sawah. Maka sudah dapat dipastikan kurang lebih 5.501 hektar lahan sawah, secara gradual akan beralih fungsi ke penggunaan lain. Prinsip pengendalian tahapan alih fungsi lahan pertanian pangan ini pada dasarnya mengatur sedemikian rupa agar:

- Lahan pertanian pangan seluas 492 hektar yang berada Pada Kawasan Pertanian Pangan di wilayah Kecamatan Purbaratu, Cibeureum, mengkubumi dan Kawalu harus dipertahankan agar tidak beralih fungsi. Lahan pertanian pangan pada kawasan tersebut harus dilindungi dan ditetapkan menjadi Lahan Pertanian Pangan Berkelanjutan (LP2B).

- Lahan pertanian pangan diluar itu, yang menyebar di seluruh wilayah kecamatan Kota Tasikmalaya, tahapan eksekusi alih fungsinya harus dikendalikan. Prinsip pengendaliannya, diatur sedemikian rupa agar lahan-lahan pertanian pangan produktif mendapat tahapan eksekusi yang paling akhir dalam proses alih fungsi. Sementara lahan pertanian yang kurang produktif dapat didahulukan.

Variabel yang menjadi acuan pertimbangan dalam pengendalian alih fungsi lahan ini diantaranya adalah: 


\section{Kajian Alih Fungsi Lahan Pertanian Pangan \\ Di Kota Tasikmalaya \\ DJONI, SUPRIANTO DAN ERI CAHRIAL}

\section{a. Sistem Pengairan}

Berdasarkan sistem pengairannya lahan pertanian pangan dapat dikelompokkan kedalam dua kategori, yaitu lahan irigasi dan lahan tadah hujan. Lahan irigasi hendaknya ditempatkan pada urutan paling akhir dalam proses alih fungsi lahan pertanian pangan dibandingkan dengan lahan pertanian pangan yang berpengairan tadah hujan.

\section{b. Letak lahan pada jaringan irigasi}

Berdasarkan letak lahan dalam jaringan irigasi, lahan pertanian pangan dapat diklasifikasi kedalam dua kategori, yaitu lahan pertanian pangan yang berada di bagian hulu dan lahan pertanian pangan yang berada di bagian hilir. Lahan pertanian pangan yang terletak di bagian hulu pada jaringan irigasi, ditempatkan pada urutan paling akhir dalam proses alih fungsi lahan dibandingkan dengan lahan pertanian pangan yang terletak di bagian hilir. Proses alih fungsi dimulai dengan urutan lahan yang terletak di bagian hilir menuju ke lahan yang berada di bagian hulu.

\section{c. Indeks Pertanaman (IP)}

Indeks Pertnaman menunjukkan intensitas penanaman tanaman pangan pada suatu hamparan lahan. Semakin tinggi indeks pertanaman lahan maka lahan tersebut menunjukkan klasifikasi yang semakin baik. Prinsif pengendalian alih fungsi lahan pertanian pangan berbasis Indeks Pertanaman adalah mendahulukan lahan pertanian pangan yang memiliki IP kecil dibandingkan dengan yang memiliki IP besar.

Berdasarkan hasil identifikasi lahan pertanian pangan berkelanajutan, Indeks pertanaman lahan pertanian pangan di Kota Tasikmalaya berkisar antara 1-3, yaitu lahan pertanian tadah hujan sampai lahan pertanian pangan yang dapat ditanami tiga musim dalam satu tahun.

\section{d. Produktivitas Lahan}

Produktivitas lahan adalah kemampuan lahan untuk menghasilkan komoditas bahan pangan per satuan luas. Berdasarkan PP nomor 11 Tahun 2011, komoditas bahan pangan yang menjadi acuan untuk mengukur produktivitas lahan ini adalah padi, jagung, ubikayu dan ubijalar. Karena makanan pokok seluruh penduduk Kota Tasikmalaya adalah beras, maka dalam kajian ini yang dimaksud dengan produktivitas lahan adalah produktivitas padi. Prinsip pengendalian alih fungsi lahan pertanian pangan berbasis produktivitas ini, semakin tinggi produktivitas lahan maka harus diupayakan agar beralih fungsi pada bagian akhir, sementara lahan pertanian pangan yang berproduktivitas rendah ditempatkan pada bagian awal.

\section{Pengendalian Berbasis Kondisi "Sosek" Usahatani}

Berdasarkan pada faktor penyebab terjadinya alih fungsi lahan pertanian, yang disebabkan oleh faktor-faktor internal. Pengendalian alih fungsi lahan pertanian berbasis kondisi sosial ekonomi ini dapat dilakukan melalui upaya-upaya:

- Pemeliharaan Prasarana/Sarana Lahan Usahatani

- Mendorong terwujudnya kerjasama kelompok

- Pemberian insentif ekonomis

- Sosialisasi UUPA Nomor 5 Tahun 1960

- Mencegah terjadinya fragmentasi lahan

- Pencitraan terhadap profesi petani

Disamping upaya yang bersifat prefentif persuasif tersebut, pengendalian alih fungsi lahan pertanian tersebut harus dibarengi dengan upaya penegakan hukum yang tegas. Upaya pengendalian alih fungsi lahan pertanian berbasis sosial-ekonomi dimaksud dapat diuraikan secara singkat sebagai berikut.

\section{Bantuan Pemeliharaan Prasarana dan Sarana}

Berdasarkan hasil analisis ditinjau dari aspek-aspek teknis, lahan pertanian pangan di Kota Tasikmalaya pada umumnya memenuhi syarat dan kriteria yang termuat dalam Peraturan Pemerintah Nomor 11 Tahun 2011, untuk ditetapkan sebagai Lahan Pertanian Pangan Berkelanjutan (LP2B). Maka oleh sebab itu sekurang-kurangnya pemerintah daerah dapat mempertahankan dan memelihara kondisi sistem pengairan dan prasarana/sarana agar tetap kondusip untuk melakukan kegiatan usahatani. Tidak sedikit lahan pertanian yang 


\section{A MIMBAR AGRIBISNIS}

beralih fungsi karena debit air pada jaringan irigasi yang menjadi sumber pengairannya tidak lagi mencukupi.

\section{Mendorong Terwujudnya \\ Kerjasama dalam Kelompok}

Usahatani pada umumnya adalah sempit, sementara usahatani yang terlalu sempit, biaya pengadaan per satuan sarana produksi menjadi tinggi, disi lain akan menanggung beban biaya penjualan (marketing cost) yang tinggi per satuan produk hasil usahataninya. Pembinaan usahatani melalui pendekatan kelompok merupakan salah satu pendekatan solusinya. Dengan berkelompok, biaya pengadaan sarana produksi bisa lebih ditekan, begitu pula biaya pada saat akan memasarkan produk hasil usahatani dapat direduksi.

Disamping dapat menekan biaya pengadaan sarana produksi dan pemasaran, pendakatan pembinaan usahatani melalui pendekatan kelompok dapat meningkatkan posisi tawar petani. Dengan berkelompok posisi tawar petani yang lemah pada saat orang perorang akan menjadi kuat dalam kesatuan yang lebih besar, dengan demikian petani dapat berperan sebagai price maker bukan sebagai price taker.

\section{Pemberian Insentif Ekonomis}

Untuk mereduksi kesenjangan antara pendapatan petani dengan kebutuhannya, dapat diberikan subsidi petani. Pemberian subsidi dimaksudkan untuk mengurangi pembiayaan usahatani atau menambah pendapatan. Maka oleh sebab itu pemberian insentif bagi petani dapat diberikan berupa:

a. Pemberian bantuan sarana produksi usahatani, berupa pupuk, pestisida ataupun pemberian bantuan benih .

b. Pemberian bantuan alsintan, dengan pendekatan kelompok..

c. Pembebasan pajak, Pajak Bumi dan Bangunan dengan maksud untuk mengurangi beban biaya yang menjadi beban tahunan petani.

Pemberian insentif ini diharapkan akan mengurangi pengeluaran petani, sehingga dapat mengalokasikan untuk keperluan keluarga.

\section{Sosialisasi UUPA Nomor $5 / 60$}

Kepemilikan tanah tidak lagi dipandang sebagai "asset" bagi pemiliknya. "nilai ekonomi" atas tanah harus diimbangi dengan dengan "fungsi sosialnya". Peraturan Dasar Pokok-pokok Agraria, pasal 4 ayat (1) dan (2) Undang-undang nomor 5 tahun 1960 merupakan hal yang harus disosialisasikan. Pasal 6 bahwa semua hak atas tanah mempunyai fungsi sosial. Hak atas tanah apapun pada seseorang tidak dapat dibenarkan apabila tanah itu dipergunakan atau tidak dipergunakan semata-mata untuk kepentingan pribadinya, apalagi kalau hal itu menimbulkan kerugian bagi masyarakat. Dalam hal inipun pemberian insentif atas kepemilikan lahanlahan yang difungsikan sebagai lahan pertanian pangan berkelanjutan merupakan salah satu pendekatan yang bijak dan harus dipikirkan lebih lanjut implementasinya.

\section{Mereduksi Terjadinya Fragmenasi Lahan Pertanian}

Proses alih penguasaan atau kepemilikan lahan usahatani dari satu generasi ke generasi berikutnya merupakan suatu proses alamiah dan menjadi suatu keniscayaan. Secara akumulatif dalam jangka panjang proses tersebut menyebabkan rata-rata satuan luas usahatani yang sudah sempit menjadi semakin sempit. Sementara usahatani yang sempit, berada dibawah skala ekonomis, tidak dapat menjadi tumpuan kehidupan keluarga petani. Lahan usahatani yang tidak dapat mencukupi kehidupan keluarga, cenderung menjadi usaha sampingan yang intensitas pengelolaannya rendah.

\section{Pencitraan ProfesiPetani}

Profesi petani sebagai produsen penghasil produk-produk hasil pertanian untuk memenuhi kebutuhan primer harus mendapat apresiasi yang tinggi. Kalaupun secara finansial rentabilitas usahatani pada umumnya relatif rendah dibandingkan dengan rentabilitas kegiatan usaha lainnya, Profesi sebagai petani memiliki keuntungan normatif. Profesi petani sesungguhnya profesi yang sangat mulia, dapat menyediakan bahan pangan dan bahan sandang 


\section{Kajian Alih Fungsi Lahan Pertanian Pangan \\ Di Kota Tasikmalaya \\ DJONI, SUPRIANTO DAN ERI CAHRIAL}

serta bahan perumahan (papan) untuk kebutuhan banyak orang.

Maka oleh sebab itu disamping petani diberi insentif secara ekonomis, seperti telah diuraikan, berupa pemberian bantuan kemudahan mendapatkan sarana produksi, bantuan alsintan, pembinaan kelompok, pemeliharaan jaringan irigasi dan lain-lain, petani juga harus mendapat "pengakuan" eksistensinya dari pemerintah daerah.

Tidak sedikit penduduk yang berprofesi sebagai petani, namun tidak mencantumkan "petani" dalam kartu penduduknya (KTP) pada identitas pekerjaannya. Untuk masa yang akan datang pemberian bantuan yang sasaran pengambil manfaatnya adalah petani, maka hanya penduduk yang mencantumkan profesi "petani" sebagai pekerjaannya.

Pada hari-hari besar nasional, seperti Hari Kemerdekaan RI, Hari Jadi Kota Tasikmalaya dan hari besar lainnya, hendaknya dijadikan even untuk pemberian anugrah penghargaan kepada para petani yang telah berprestasi. Dengan cara pemberian penghargaan seperti ini, diharapkan profesi sebagai petani memiliki "status simbol" yang tinggi.

Penyelenggaraan pameran dan even pemberian penghargaan kepada petani dikemas sedemikian rupa, tidak hanya bernuansa tradisional namun juga dipaduserasikan dengan unsur-unsur modern. Dengan memadukan unsur-unsur modern diharapkan profesi petani tidak lagi dipandang "kolot" namun dapat bernuasa modern yang dianggapnya "keren" sehingga dapat menarik minat generasi muda untuk berperanserta dalam dibidang pertanian.

\section{PENUTUP}

Luas wilayah Kota Tasikmalaya berdasarkan UU/10/2010 adalah 17.256,20 hektar. Seluas $12.519 \mathrm{Ha}$, diantaranya adalah lahan pertanian, yang terbagi kedalam dua kategori, yaitu: lahan sawah 5.993 Ha dan lahan bukan sawah 6.526 hektar. Berdasarkan sistem pengairannnya lahan sawah terdiri dari lahan sawah irigasi $5.055 \mathrm{Ha}$ dan sawah tadah hujan $938 \mathrm{Ha}$

Pada tahun 2008 luas lahan sawah masih 6.184 Ha. Selama periode delapan tahun terakhir terjadi alih fungsi lahan sawah seluas $191 \mathrm{Ha}$.

Berdasarkan sistem pengairannnya lahan sawah terdiri dari lahan sawah irigasi 5.055 hektar dan sawah tadah hujan 938 hektar. Selama periode delapan tahun terakhir terjadi alih fungsi lahan sawah seluas $191 \mathrm{Ha}$.

Faktor-faktor yang mempengaruhi alih fungsi lahan pertanian dapat dibagi kedalam dua kategori, yaitu: yaitu faktor internal dan faktor ekternal. Faktor internal meliputi Faktor Teknis; Faktor Ekonomis dan Faktor sosial. Sementara faktor ekternal yang mempenagruhi alih fungsi lahan pertanian diantaranya adalah laju pertumbuhan penduduk, kebijakan pembangunan pemerintah (daerah) dan Rencana Tata Ruang Wilayah (RTRW).

Pengendalian alih fungsi yang disebabkan oleh faktor internal dilakukan melalui pendekatan aspek teknis, aspek sosial, dan aspek ekonomi usahatani. Variabel yang menjadi acuan dalam pengendalian teknis alih fungsi lahan ini diantaranya: a. Sistem Pengairan ; b. Letak lahan pada jaringan irigasi; c. Indeks Pertanaman (IP); d. Produktivitas Lahan.

Pengendalian alih fungsi lahan pertanian berbasis kondisi sosial dapat dilakukan melalui upaya: Pemeliharaan Prasarana/Sarana Lahan Usahatani; Mendorong terwujudnya kerjasama kelompok; Pemberian insentif ekonomis; Sosialisasi UUPA Nomor 5 Tahun 1960; Mencegah terjadinya fragmentasi lahan ; Pencitraan terhadap profesi petani; Pengendalian alih fungsi lahan pertanian yang disebabkan oleh faktor eksternal yang dalam hal ini terdiri dari: Pengendalian penggunaan lahan agar sesuai dengan RTRW; Pengendalian tahapan penggunaan lahan.

\section{DAFTAR PUSTAKA}

Badan Pusat Statistik Kota Tasikmalaya, 2015. Kota Tasikmalaya Dalam Angka. Tasikmalaya.

Entang Sastraatmaja. 2014.Ketahanan dan Kedaulatan Pangan Daerah.(Makalah Rakor Pangan Kabupaten Tasikmalaya).

Eddy Ruchiyat (1983). Pelaksana Land reform dan jual gadai tanah. Armico, Bandung. 


\section{A MIMBAR AGRIBISNIS}

Volume 1 - Nomor 3 Juli 2016

Koentjaraningrat, 1989. Metode-Metode

Penelitian Masyarakat. Gramedia.

Jakarta.

Tarlan. 2005. Hubungan Luas Dan Status

Penguasaan Lahan Dengan

Pelaksanaan Penghijauan. Di

Kabupaten Tasikmalaya.

Perundang-undangan

Undang-Undang Nomor 41 Tahun 2009 tentang Perlindungan Lahan Pertanian Pangan Berkelanjutan (Lembaran Negara Republik Indonesia Tahun 2009 Nomor 149, Tambahan Lembaran Negara Republik Indonesia Nomor 5068); 